\title{
Jean Raspail, Michel Houellebecq, and Jenny Erpenbeck: Acknowledging the Barbarian Within
}

\author{
John HAWLEY' (1)
}

'Prof., Santa Clara University, Department of English, California, USA

ORCID: J.H. 0000-0002-3040-6250

\section{Corresponding author:}

John HAWLEY,

Santa Clara University, Department of

English, 500 El Camino Real

Santa Clara, California 95053 USA

E-mail: jhawley@scu.edu

\section{Submitted: 22.01.2019}

Accepted: 28.03.2019

Citation: Hawley, J. (2019). Jean Raspail, Michel Houellebecq, and Jenny Erpenbeck: Acknowledging the Barbarian. Litera, 29(1), 1-18.

https://doi.org/10.26650/LITERA2019-0003

\section{ABSTRACT}

This paper seeks to discuss recent sites of contestation of the implications one assigns to migration from Africa and the Middle East to Central and Western Europe. It will be predominantly Eurocentric in its data and analysis, dealing less with the motivations of the migrants and the second generation, and more with the various responses to that migration among Europeans (e.g., what are "they" doing to "us"). The major literary texts involved in the paper will be Michel Houellebecq's Submission (2015), and Jenny Erpenbeck's Go, Went, Gone (2015), with initial consideration of Jean Raspail's The Camp of the Saints (1973). In these encounters, the overriding question is less "Who are these people," than "Who are we in the face of these others?" Despite their varying motivations, they are texts that continue to define Europe by viewing it against the backdrop of the other. I will conclude with a reference to two projects that seek to engage viewers/readers vicariously in the lived experiences of particular Africans forced to flee their homes. Such empathy elicits an aggressively negative reaction among some Europeans, a white paranoia that foresees the extinction of a romantically imagined pure ethnically-based culture and recalls earlier campaigns with similarly violent results.

Keywords: Migration, Nationalism, Xenophobia, France, Germany 


\section{Introduction}

Serving as bishop of Hippo Regius in what is now Annaba, Algeria, St. Augustine reflected on the transience of the human condition. Reflecting in Book IV of his Confessions on the philosophy in the letter to the Hebrews ("We have not here a lasting city, but we are looking for the City that is to come," xiii, 14), he possibly looked out onto the Mediterranean and heard in the crash of the waves a hint of what was to come. Centuries later, Médine Zaouiche, a practicing Muslim born in Le Havre in 1983, is a French-Algerian-Berber rapper. "All I ever wanted was to play the Bataclan," he once said (Beardsley, 2018, para. 20). He had been scheduled to play at the Bataclan theatre in Paris on the 2018 anniversary of the attack there in November 2015, but he was cancelled after protests by Marine Le Pen and others who characterized his lyrics as divisive. Médine was not surprised. In an article in Time magazine ten years earlier, entitled "How Much More French Can I Be?," contrasting himself to his assimilationist parents who tried to avoid calling attention to themselves as immigrants, Médine wrote: "But people of my generation are not shy about embracing their heritage, and, far from seeking invisibility, we're standing up to denounce the prejudice and injustice we face. In my case, Islam is an enormous part of who I am, just as being French is. The two aren't in opposition or even mutually exclusive. Yet when you hear the debate in France today, you'd swear they must be" (Zaouiche, 2005, para. 2). That attitude of being fully French might explain his desire to "play the Bataclan," a venue designed by Charles Duval in 1854 and hosting such national luminaries as Edith Piaf and Maurice Chevalier. In more recent years and leading up to its bombing it was criticized for its pro-Israel events. Médine's cancellation as a result of the protests from Le Pen suggests that nothing favorable to his argument had taken place since 2005, when he concluded his Time article with these words: "the gap between the banlieue and the rest of France must be bridged. We need to make peace with the things that make us different. I'm French, I'm Muslim, and there are millions like me. We live here, and we're not going anywhere. So let's start getting used to it" (Zaouiche, 2005, para. 5).

Indeed, France has not become used to it. In the Afterword to his controversial The Camp of the Saints (1973), its author recounts how he felt the call to write such a book:

One morning in 1972, at home by the shore of the Mediterranean, [l] had a vision: They were there! A million poor wretches, armed only with 
their weakness and their numbers, overwhelmed by misery, encumbered with starving brown and black children, ready to disembark on our soil, the vanguard of the multitudes pressing hard against every part of the tired and overfed West. I literally saw them, saw the major problem they presented, a problem absolutely insoluble by our present moral standards. To let them in would destroy us. To reject them would destroy them. (Raspail, 2017, p. 313)

Eleanor Beardsley, referring to the lyrics of a Médine song--"Your beard, my brother, it's don't laïk / Your veil, my sister in this country, it's don't laïk" (para. 7)--notes the unfortunate timing of the song's release: "The song, which talks of 'crucifying the secularists like at Golgotha,' happened to come out just a week before terrorists killed twelve people at the satirical weekly magazine Charlie Hebdo in 2015" (Beardsley, 2018, para. 8). Nonetheless, recent studies suggest that Médine well represents his generation, who "regard themselves not as marginal, ethnic commentators on French society, but rather claim their place as full-fledged members and renovators of French literature and cinema at large" (Machelidon, 2018, p. 3). In recent years they "go beyond the formulaic beur or banlieue cinema of the 1980s and 1990s respectively" (Machelidon, 2018, p. 3) and, according to several recent studies, "steer away from the leitmotifs of integration (Durmelat and Swamy, 2011, p. 3) and split identity, which characterized the production of the 1980s and 1990s, to emphasize a sociological and cultural reality which is less easily appropriated by hegemonic discourse" and "transcends the geography of the local, represented by the substandard life-styles of the cité (housing project) and the culturally impoverished banlieue, to embrace richly diverse projects, stories and cultures that pertain to the national and transnational" (Durmelat and Swamy, 2011, p. 4). The empire has come home to roost.

This paper seeks to discuss recent sites of contestation of the implications of migration from Africa and the Middle East to Central and Western Europe. It will be predominantly Eurocentric in its data and analysis, dealing less with the motivations of the migrants and the second generation, and more with the various responses to that migration among Europeans (e.g., what are "they" doing to "us," as seen in the Raspail quote above that, one might say, "responds" to Médine: Raspail there references what he describes as "the tired and overfed West," encumbered by inadequate "present moral standards"). The major literary texts involved in the paper will be Michel Houellebecq's Submission (2015), and Jenny Erpenbeck's Go, Went, 
Gone (2015), with initial consideration of Jean Raspail's The Camp of the Saints (1973). In all of these encounters, the overriding question is less "Who are these people," than "Who are we in the face of these others?" Despite their varying motivations, they are texts that continue to define Europe by viewing it against the backdrop of the other.

Such empathy elicits an aggressively negative reaction among some Europeans, a white paranoia that foresees the extinction of a romantically imagined pure ethnically-based culture and recalls earlier campaigns with similarly violent results. ${ }^{1}$ As recently as March of 2018, for example, Inger Stojberg, Denmark's immigration minister, "suggested that Muslims fasting for Ramadan should stay home from work 'to avoid negative consequences for the rest of Danish society'. . . She called adherence to the religious practice 'a danger to all of us'" (NYTimes 5/23/2018 A9). On her facebook page, with a picture of a cake, she celebrated the passing of the country's $50^{\text {th }}$ immigration restriction, which includes "a law requiring newly arrived asylum seekers to surrender valuables like jewelry and gold to help pay for their stay in the country" (NYTimes 5/23/2018 A9). There is a similar law in Germany and Switzerland.

\section{Le Camp des Saints and the Death of Western Civilization}

One is not surprised, therefore, that Jean Raspail's 1973 Le Camp des Saints, depicting the destruction of Western civilization through Third World mass immigration to France, returned to the bestseller list in 2011. ${ }^{2}$ The book anticipates and ridicules cries of common humanity heard in the twenty-first century reactions to the great migrations across borders. The wretched novel tells the story of the dispatch of one hundred ships from India to France, carrying one million people. Suggesting the overwhelmingly negative response he may have expected, Raspail says he chose India (rather than Africa or the Middle East, one supposes), out of "prudence" and his "refusal to enter the false debate about racism and anti-racism in French daily life" (Raspail, 2017, p. xv). He concedes, though, that "to be sure, a mighty vanguard is already here, and expresses its intention to stay even as it refuses to assimilate" (Raspail, 2017, p. xv). The narrator yearns for an earlier France and despises

1 And recalls the famous words from Martin Niemöller. (https://encyclopedia.ushmm.org/content/en/article/ martin-niemoeller-first-they-came-for-the-socialists) Accessed 26 March 2019.

2 See a recent interview with Raspail: https://www.youtube.com/watch?v=iX1INqJS7ug Accessed 26 December 2018, in which he is described as Cassandra. 
what he reads as the decadence of his contemporaries, with their lazy acquiescence to the invasion (their "mannered mentality, a collusion of aesthetes, a conspiracy of caste, a good-natured indifference to the crass and the common" [Raspail, 2017, p. 257]). The book, as one favorable review describes it, chronicles the end of the twenty courageous men who resist the conquest of the "white world" (Williamson, 2018, para. 6). Soon, the "debarking hordes" amount to eight million. In the novel, many French citizens sympathize with the migrants; soldiers desert their posts; the banlieues rise up. White women are enslaved in brothels for the foreign invaders. But a few "Saints" make a last stand, recognizing their sure defeat but proud to make a point:"we've got to put some order in that filthy mess somehow. Even if it won't make a damn bit of difference. We're a symbol. Those freaks are a symbol. So we'll spray them with a round of symbolic bullets, and if some of them croak, well, so much the better" (Raspail, 2017, p. 261). The machine gun fires, then silence: "There's nothing more ghastly to watch than misshapen gnomes or mental misfits writhing in pain. Caricatures of suffering bodies. Blank, gaping stares, trying to comprehend. Blood flowing from monstrous, malformed flesh" (Raspail, 2017, p. 261). With the collapse of France, the rest of the white world quickly follows suit. "At No. 10 Downing Street, negotiations are in progress. The Non-European Commonwealth Committee has taken over London, politely as you please.... In the Philippines, in all the stifling Third World ports—Jakarta, Karachi, Conakry, and again in Calcutta-other huge armadas were ready to weigh anchor, bound for Australia, New Zealand, Europe" (Raspail, 2017, p. 286).

In the Introduction to the 1985 French edition of his novel, Raspail condemns his countrymen for their liberal Christian naïvete: "Under the flag of an illusory internal solidarity and security," he writes, "they are no longer in solidarity with anything, or even cognizant of anything that would constitute the essential commonalities of a people. In the area of the practical and materialistic, which alone can still light a spark of interest in their eyes, they form a nation of petty bourgeois which, in the name of the riches it inherited and is less and less deserving of, rewards itself-and continues to reward itself in the middle of crisis-with millions of domestic servants: immigrants" (Raspail, 2017, p. xvi). The phrase "essential commonalities of a People" surely smacks of the ominous "Das Volk," in all its purported glory.

3 See Roger Cohen's "Return of the German Volk." New York Times 29 September 2017 (https://www.nytimes. com/2017/09/29/opinion/german-election-afd.html) Accessed 31 December 2018. 


\section{Submission and the Death of the Western Weltansschauung}

Michel Houellebecq's implied critique of his countrymen-and-women in Submission (2015) follows a similar line, though Houellebecq is far subtler and much more interesting. His novel was released on the day of the Charlie Hebdo shooting (thus, one week after the release of Médine's controversial song), and its author appeared on the cover of that week's issue under the heading: "The predictions of the sorcerer Houellebecq: In 2015, I lose my teeth. In 2022, I observe Ramadan." Arguably an updating of Raspail's controversial jeremiad, Submission was chosen by the New York Times Book Review as a notable book of the year and described by Time magazine as "the most relevant book of the year" (D'Addario, 2015, para. 1).

Set in 2022, the novel presents François, its 44-year-old protagonist, as a literature professor who has been teaching at the University of Paris III for fifteen years. He is the world expert on Joris-Karl Huysmans (1848-1907), who was a founder of the French decadent movement, a pessimistic follower of Schopenhauer, and later a convert to Roman Catholicism. As with many scholars, François identifies in many ways with his subject matter, sometimes seeming to be a reincarnation of Husymans, that controversial personification, one could argue, of the French Zeitgeist of the late nineteenth-century. François is a bit of a gourmet, of food and of sex, but he has become tired of both, to his increasing dismay. The growing malaise presents him with a sense of an ending. In fact, he seems at about the same point in his life as the protagonists in recent novels that portray the unexpected transformation into bombers of apparently successful Middle Eastern or Pakistani migrants who go to Princeton, get careers on Wall Street, and then, finding their lives utterly soulless, turn to a fundamentalist political Islam.

As his cultural tether begins to loosen and he looks out onto a nation that appears to him to share his existential dilemma, France's/François's attention becomes increasingly focused on the growing number of migrants becoming politically active and fully convicted in their faith. Adam Shatz, in his generally favorable review of the novel for the London Review of Books, reminds readers of Charles DeGaulle's views on, more or less, the "essential commonalities" of his fellow citizens: in 1959 he told an interviewer,

Do you believe that the French nation can absorb 10 million Muslims, who tomorrow will be 20 million and the day after 40 million? If we 
adopt integration, if all the Arabs and Berbers of Algeria were considered as Frenchmen, what would prevent them from coming to settle in mainland France where the standard of living is so much higher? My village would no longer be called Colombey-les-Deux-Eglises, but Colombey-les-Deux-Mosquées! (Schatz, 2015, para. 3).

Shatz does not see Houellebecq's novel as anti-Islamic, though. As he writes, "Soumission is too ambiguous to be read as satire - or, for that matter, as nightmare. There are strong indications, both in the novel and in interviews, that Houellebecq sees Islam as a solution, if not the solution, to the crisis of French civilization" (Schatz, 2015, para. 20). As another reviewer writes, "It's not Muslims whom Houellebecq is scared of. It's the future" (D'Addario, 2015, para. 6). Submission, in short, provides a platform for a lively consideration of the "settling" that De Gaulle warned against, and what some see as the adulteration of "Frenchness" - that je ne sais quoi.

Notably, though, there are few actual migrants portrayed in the novel, though their presence, and that of their now-adult children, is the powerful, savvy foreign mass of unknown Others gathering forces just off-stage, and then finally center stage as their political party gains the Presidency through an alliance with the French Socialist party (and by defeating Marine Le Pen). Mohammed Ben Abbes leads the Muslim faction, and his calm, reasonable interactions make him seem the most sane, least self-centered character in the book. Opposing his methodical rise to power is the protagonist's growing despair: he wakes at three in the morning, looks out on Paris in an ever-present twilight, and sees "a few thousand apartments in all, a few thousand households - which by now tended to mean two people or, more and more often, just one. Most of the cells were dark. I had no more reason to kill myself than most of these people did.... And yet I knew I was close to suicide, not out of despair or even any special sadness, simply from the degradation of 'the set of functions that resist death', in Bichat's famous formulation. The mere will to live was clearly no match for the pains and aggravations that punctuate the life of the average Western man" (Houellebecq, 2015, p. 168).

Sounding much like Sartre, he concludes: "Humanity didn't interest me-it disgusted me, actually. I didn't think of human beings as my brother, especially not when I looked at some particular subset of human beings, such as the French" (Houellebecq, 2015, p. 169). His body revolts against itself, persecuting him with an extremely violent outbreak 
of hemorrhoids and a painful outbreak of dyshidrosis (tiny pustules spread across the soles of his feet). His growing isolation and alienation is literally immobilizing him. He reverts to Huysmans's response to a similar crisis, which was to return to religion, but quickly decides that this is just a "radical exoticism" (Houellebecq, 2015, p. 169). It's no surprise that, when he receives not a single New Year's greeting, he "burst into unexpected tears and couldn't stop crying" (Houellebecq, 2015, p. 170).

His solution, finally, is to submit. In effect, he surrenders France to the migrants. He epitomizes the very class that Raspail's narrator despised, and that Raspail grudgingly acknowledged were choosing the only "successful" route open to them, since they would not violate their absurd moral norms by repulsing the migrants. François makes one last desperate retreat to Ligugé Abbey, "the oldest Christian monastery in the West" and the site where Huysmans had become a Benedictine oblate. François had been there twenty years earlier, to reasonably good effect, but now, he sadly concludes, "I no longer knew the meaning of my presence in this place. ... In any case, it clearly had little to do with Huysmans anymore" (Houellebecq, 2015, p. 177). Like many traditionalist Catholics, he finds the "modern church... had a sober ugliness to it. Architecturally, it was reminiscent of the Super-Passy shopping center" (Houellebecq, 2015, p. 178). He leaves the abbey, stops in a diner, becomes disgusted by the other customers "talking in loud voices, mainly about real estate and vacations. It gave me no satisfaction to be back among people like myself" (Houellebecq, 2015, p. 180)-in effect, vacations rather than vocations.

Houellebecq begins the book's final section with a quote from Ayatollah Khomeini: "If Islam is not political, it is nothing," and Ben Abbes wastes no time before he's insulting the Saudis and aligning France with the Qataris, negotiating to bring Algeria and Tunisia into the EU, commencing preliminary talks with Lebanon and Egypt, and the argument is made that "with the addition of the Arab states, the linguistic balance of Europe is going to shift toward France" (Houellebecq, 2015, p. 239)—so, a win/win all around. One of François's acquaintances points out that medieval Christendom had made a fatal compromise with rationalism, and thereby had renounced its temporal powers "and so had sealed its doom" (Houellebecq, 2015, p. 226). On his way to the Institut du Monde Arabe François makes it a point to emerge from the Place Monge metro station, describing it as "a hollow carved out of the walls of the park, its thick columns, cubist typography, and generally neoBabylonian appearance all completely out of place in Paris-as they would have 
been pretty much anywhere else in Europe" (Houellebecq, 2015, p. 197)-as if suggesting that the invasion had begun surreptitiously long ago, hidden in plain sight and now stepping forth from the shadows, in France and throughout the rest of Europe. But he comes to see this not as Raspail's paranoid clash of civilizations, but as a needed evolution. ${ }^{4}$ His former colleagues at work (he was made redundant after the election of Abbes, when his school is renamed the Islamic University of Paris, employing only Muslims) ${ }^{5}$ suddenly find themselves with second wives, some just fifteen years of age. It is suggested that François himself, based upon his professorial salary, "could have three wives without too much trouble" (Houellebecq, 2015, p. 240). None of the professors is complaining about the changes, the increasing apartheid between males and females throughout Paris, the infantilization of women. When the dean invites François to consider returning to the school-providing he first convert, of course- François is won over by the argument that he, and all of France, all of the West, lack commitment to anything at all. The dean reminds him that "in the rest of the world people die and kill in the name of these very questions, they wage bloody wars over them, and they have since the dawn of time. These metaphysical questions are exactly what men fight over, not market shares or who gets to hunt where" (Houellebecq, 2015, p. 204). This, apparently, is a good thing.

Readers may be surprised when François's reaction to this is: "For the first time in my life I'd started thinking about God" (Houellebecq, 2015, p. 214)—this from someone who had devoted his academic life to the study of medieval and nineteenthcentury Catholicism. Even more surprising, perhaps, is his own first emotion to this reconsideration of God, which is "uncomplicated, pure and simple fear" (Houellebecq, 2015, p. 214). His life's work with Huysmans now seems to have been misguided: "the infinite spaces that terrified Pascal, that inspired in Newton and Kant such awe and respect, Huysmans seems never to have noticed. He was a convert, certainly, but not along the lines of Péguy or Claudel. My own dissertation, I now realized, would not

4 As Adam Gopnik suggests, the popularity of Sabri Louatah's Les Sauvages (2012) suggests that the French are more sophisticated in their imagination of a complex Arab-French President than Houellebecq may be giving them credit for.

5 Gopnik notes that "The idea of an overnight Muslim takeover, where suddenly the University of Paris becomes the Islamic University of Paris, perches at the back of the European apocalyptic imagination, perhaps because it once really happened. On the morning of May 28, 1453, Constantinople was still a Christian city. The next day, it wasn't. ... The notion that you wake up and there's the Eiffel Tower with a crescent moon and star upon it haunts the Western imagination of catastrophe."

Gopnik, Adam. "The Next Thing: Michel Houellebecq's Francophobic Satire," The New Yorker 26 January 2015 online (https://www.newyorker.com/magazine/2015/01/26/next-thing) Accessed 26 March 2019. 
be much help to me; and neither would Huysmans's own protestations of faith" (Houellebecq, 2015, p. 216). Perhaps the Husymans he knew was more of an aesthete than a believer.

Early in the novel, François had declared that "in the end, my dick was all I had" (Houellebecq, 2015, p. 79). Now he notices that "as the new Islamic regime pushed women's clothing in the direction of decency, I had felt my own sexual impulses gradually diminish. I sometimes went whole days without thinking of sex" (Houellebecq, 2015, pp. 229-230). At the same time, he becomes "more aware with every step that. . . my intellectual life really was over" (Houellebecq, 2015, p. 232) but concludes that "life might actually have more to offer" (Houellebecq, 2015, p. 242). As François takes Islam more seriously, he hunts down the dean's academic publications, ultimately discovering one in which the dean had proclaimed that Islam had been chosen for world domination. As scary as he might once have found the article, François moves toward affirmation, arguing, for example, that multiple wives, even much younger ones, would be preferable to "hitting on his students" (Houellebecq, 2015, p. 242)—as he had formerly done. He finally submits, acknowledging the gift that had been brought to France by migrants: "This wave of new immigrants, with their traditional culture-of natural hierarchies, the submission of women, and respect for elders-offered a historic opportunity for the moral and familial rearmament of Europe. These immigrants held out the hope of a new golden age for the old continent" (Houellebecq, 2015, p. 226). Readers are left to ponder this ambiguous conclusion-droll, sincere, or simply intentionally provocative? Adam Gopnik is probably correctly analyzing Houellebecq's pointed (and hardly migrantwelcoming) thesis: "Like the oversophisticated Hellenists in Cavafy's poem, [the French élite] have been secretly waiting for the barbarians all their lives" (Gopnik, 2015, para. 1). Houellebecq's satire ultimately gives the reader much to think about, but offers not the slightest empathy, from start to finish, for any of its characters.

\section{Go, Went, Gone, and the Rebirth of the Civilized Westerner}

Jenny Erpenbeck's Go, Went, Gone is a book of quite a different caliber, a tale of borders of all sorts dropping, with consequent uncharted consequences for its characters. The novel begins on the day its protagonist, Richard, professor of classical philology at Humboldt University in Berlin and author of The Concept of the World in the Works of Lucretius and two books about Seneca, retires and begins his puttering in 
his garden, checking for molehills, possibly hoping to make them into meaningful mountains, seeming just a bit like Prufrock. As the narrator puts it, "Richard is waiting but he doesn't know for what" (Erpenbeck, 2017, p. 4); technically retired, "he can't stop thinking. The thinking is what he is. ... even if no one gives a hoot what he thinks" anymore (Erpenbeck, 2017, p. 4). In this regard, he epitomizes one of the stereotypes of "the German," in much the way that the ennui-obsessed François embodied a French "type." And, like François he is an academic, one who has accomplished much, but is now basically alone in the world, with scant reference to his dead wife Christel, and with no set course. He knows he is "one of very few people in this world who are in a position to take their pick of realities" (Erpenbeck, 2017, p. 219), but convinced with Hölderlin by "the thought of everlasting flux and the ephemeral nature of all human constructs, the sense that all existing order is vulnerable to reversal" (Erpenbeck, 2017, p. 241). The question is: what next action is worth the trouble?

Erpenbeck quietly suggests that her protagonist is, himself, a bit of a migrant. He had been an East Berliner but "in 1990 he suddenly found himself a citizen of a different country" (Erpenbeck, 2017, p. 81), still trying to find his way in a reunited city that seems like a new world in which he is uncertain of his role, still getting lost when he leaves an S-Bahn station in West Berlin. Dissolution on many levels-of memories, of flesh, of national ethos-haunts this trained philosopher as his retirement opens vistas onto an uncertain future: "Now that the Wall is gone, he no longer knows his way around" (Erpenbeck, 2017, p. 29). He seems to identify with a recurring image that sets the tone of the book in the opening pages: outside his home is a lake, and at its bottom is a drowned man whose body has not yet been recovered. Like the character in the famous Stevie Smith poem, "they saw the man waving his arm and thought it was a joke" (Erpenbeck, 2017, p. 5), prompting Richard to ask himself "what separates a surface from what lies below it" (Erpenbeck, 2017, p. 31).

As the book progresses, this image nicely describes Richard, as well as the migrants arriving from various parts of Africa. He seems amazed that friends around him continue on with their lives, apparently oblivious to the drowned man-and to the many others who are waving their arms (including, perhaps, himself). Sounding a bit like Freud, the narrator frequently reminds the reader that "they still haven't found the man at the bottom of the lake" (Erpenbeck, 2017, p. 5). His friends move on with their lives but he, like the philosopher that he is, "can't avoid seeing the lake when he 
sits at his desk" (Erpenbeck, 2017, p. 5). Despite the world's indifference, he sees it as his duty to avoid the superficial, to connect things, incidents, and find meaning. As he notes, "it makes no difference to the lake whether it's a fish decomposing beneath its surface or a human being" (Erpenbeck, 2017, p. 7), but Richard is increasingly obsessed with the value of the individual anonymous human being that the world simply absorbs back into its essential meaninglessness.

When he walks by a small gathering of migrant African men in Alexanderplatz, barely noticing them, and then returns again and again, he reads their sign that says "We become visible" (Erpenbeck, 2017, p. 14), which he finds ironic since the Berliners in the buildings around the square, like those in the Fitness Center "bicycling and running toward the enormous windows hour after hour," remain oblivious to the Africans and disconnected from them: "It's quite possible that these fitness-minded individuals can observe everything happening on Alexanderplatz in front of them, but they probably wouldn't be able to read, say, the words on the sign-for that, they're too far away" (Erpenbeck, 2017, p. 15). When the demonstration is cleared, Richard feels a mild regret: "He'd liked the notion of making oneself visible by publicly refusing to say who one is. Odysseus had called himself Nobody to escape from the Cyclops's cave" (Erpenbeck, 2017, p. 22). When reporters show up on the scene, Richard refuses to give his own name-becoming as anonymous as the Africans, but no longer comfortably myopic. Willy nilly, he finds that he cannot remain so far from the Africans. "As a child," he recalls, "he learned the meaning of adversity. But that doesn't mean he has to starve himself just because a desperate man has begun a hunger strike. Or so he tells himself. . . . For him, refusing to eat would be just as capricious as gluttony" (Erpenbeck, 2017, pp. 18-19). Eating his dinner in front of the television, noticing how delicious the tomato tastes, he reflects on the news coverage and becomes confused:

What stories lay behind all the random images constantly placed before us? Or was it no longer a matter of storytelling? Today alone, six people died in swimming accidents in the greater Berlin area, the newscaster says in conclusion, a tragic record, and now it's time for the weather. Six people just like that man still at the bottom of the lake. We become visible. Why didn't Richard see these men at Alexanderplatz? (Erpenbeck, 2017, p. 19) 
His friends continue to meet over drinks and share their increasingly pettyseeming life choices. Richard is, if anything, even less romantic or naïve than is Houellebecq's François: coming in from mowing the lawn and taking down from the shelf the Odyssey, Richard reads again his favorite chapter, in which Odysseus is surprised in Hades to see Elpenor, one of his crew that he had not noticed; he meets his mother, and Tiresias, who tells him that he alone will survive the journey, and Richard glumly reflects on the human condition: "The earth is more like a garbage heap containing all the ages of history, age after age there in the dark, and all the people of all these ages, their mouths stopped up with dirt, an endless copulation but no womb fertile, and progress is only when the creatures walking the earth know nothing of all these things." (Erpenbeck, 2017, p. 21)

Richard sees himself as one of these creatures walking the earth, powerful in the eyes of the world and physically very comfortable, but nonetheless an existential migrant similar to those reflected upon by St. Augustine-Augustine himself influenced by Plotinus, in turn influenced by Plato. Richard's mind is a palimpsest of western philosophy ("everything," he thinks, "is always already there" [Erpenbeck, 2017, p. 37])-it's all a matter of getting beneath surfaces-and the conversation among these ideas in the history of philosophy is as alive for him as will be the conversations he soon has with the migrants in the square.

In fact, he translates several of the Africans into characters in European mythologies-Hermes, Apollo, Tristan. Such a "carrying over" of meaning is an imposition rather than a true encounter with these individuals, but it provides an opening for later more significant conversations with them and demonstrates Richard's Proustian dissolution of the permeable membrane separating one day from the next, one memory from the last, in fact one continent from another. He begins to actually see the random individuals thrown on his shore from Africa as a slow distinguishing, beginning with the recognition that Africa is composed of 54 countries, Burkina Faso is located in this place on the map, the capital of Niger is Niamey. He takes from his shelf the dated book Negerliteratur (1951) that he had never read ("The earth is round and completely surrounded by swamp. Behind the swamp lies the land of the bush spirits"). He recalls his mother reading to him about "the little cannibal boy" (Erpenbeck, 2017, p. 24) in Hatschi Bratschi's Luftballon (1960) remembering, perhaps only subliminally, that Hatschi Bratschi himself is an evil wizard who eats children. True to his philosophical bent, he notes that the 
determination of which books attract his attention in a particular year is unpredictable, as is the consequent redefinition of his role in the world around him: "The workings of causality are indirect, not direct, he thinks" (Erpenbeck, 2017, p. 24), "the effects of a person's actions are almost always impossible to predict" (Erpenbeck, 2017, p. 35). Randomness, flux, as in the deaths of those who drown during the crossing, and those that make it to Lampedusa. "A border," it occurs to him, "is a place where, at least in mathematics, signs often change their value" (Erpenbeck, 2017, p. 35). So many abstractions, and yet they gradually become the faces of particular migrants.

Richard recognizes that his own crossing over will be uncertain. He looks at fellow Berliners who sit with the Africans in awkward solidarity: "The sympathizers are young and pale, they dye their hair with henna, they refuse to believe that the world is an idyllic place and want everything to change, for which reason they put rings through their lips, ears, and noses. The refugees, on the other hand, are trying to gain admittance to this world that appears to them convincingly idyllic" (Erpenbeck, 2017, p. 33). The silent presence of these Africans reorders the world for Berliners (like Wallace Stevens placing a jar in Tennessee), sitting on their familiar park benches but "no longer certain" how to comport themselves (Erpenbeck, 2017 , p. 34). Sitting on such a bench, "he wonders whether, back when there was still a canal right where he's sitting now, slaves were sold at that department store" (Erpenbeck, 2017, p. 37); he wonders if these Africans knew who Hitler was, and muses that "only if they survived Germany now would Hitler truly have lost the war" (Erpenbeck, 2017, p. 50). And so his personal story slowly comes into focus as a national parable.

Eventually, Richard hears the stories of a group of 14 Africans from various countries, who make up something of a Schindler's List of individuals that are taken in by Richard and a few others to protect them from the authorities. In this didactic novel readers are taught the histories of the various migrations, their causes, their routes, the legal complexities of Dublin II and Italian work laws, the absurdities of the "certificate of fiction" (Fiktionsbescheinigung) - "a confirmation that this person existed who had not yet been granted the right to call himself a refugee" (Erpenbeck, 2017, p. 82). The narrator records Richard's conversations with the migrants as they tell him the specifics of what led them to leave their homelands, the route they have taken, the incredibly frustrating and contradictory 
national laws that slow their assimilation. In the migrants' innocent vulnerability he finds renewed hope that he might be transported to "the Germany of before, to the land already lost forever by the time he was born" (Erpenbeck, 2017, p. 120), but counters it with a line from Brecht: "He who laughs has not yet received the terrible news" (Erpenbeck, 2017, p. 124). Raising his head from the individuals, moving from the particular to the abstract, he recalls that the path of the Berbers, over thousands of years, may have gone through Anatolia and the Levant to Egypt, then Niger, then Libya, Rome, and finally Berlin, and he casts their history against Hesiod's Works and Days and the five ages of mankind-a book he can recite from memory. He thus identifies with the oral histories he hears from the Africans, noting that "without memory, man is nothing more than a bit of flesh on the planet's surface" (Erpenbeck, 2017, p. 151). Again, one sees the urge to plunge beneath the surface, to connect.

His commitment becomes more practical. He scraps plans to purchase a fancy lawnmower for 3000 euros, and instead purchases a plot of land back home for the family of one of the Africans. He becomes alienated from his fellow citizens ("Have people forgotten in Berlin of all places that a border isn't just measured by an opponent's stature but in fact creates him?" [Erpenbeck, 2017, p. 211]). He allows the Africans to use his ID to register the next demonstration, and he comes up with their slogan: A Time to Make Friends. After all, he reasons, referring to Tacitus's Germania, "two thousand years ago, no one was more hospitable than the Teutons" but now "we're left with section 231, paragraph I of the Residence Act" (Erpenbeck, 2017, pp. 250-251). At novel's end, Richard has had his home officially registered as a home shelter, and has opened it to twelve Africans: Rufu, Abdusalam, Yaya, Moussa, Khalil, Mohamed, Ithemba, Apollo, Karon, Zair, Awad, and Zani. Seeking the balance that Seneca preached, Richard now finds that "the lake will forever remain the lake in which someone has died, but it will nonetheless remain forever very beautiful" (Erpenbeck, 2017, p. 276)—much like Berlin, itself. But if there was ever any question that Go, Went, Gone was about specific African migrants in contemporary Germany, the book's closing pages dispel that possibility, focusing relentlessly on what Richard has discovered about himself-though himself as embodying the human condition. Admitting his core fear of death to Khalil, he remarks: "'the things I can endure are only just the surface of what I can't possibly endure.' 'Like the surface of the sea?' asks Khalil. 'Actually, yes, exactly like the surface of the sea'"' (Erpenbeck, 2017, p. 283). 


\section{Conclusion}

That "surface" is a place to start. As Cajetan Iheka and Jack Taylor argue in their important new book, "from the vantage point of ethics and politics. .. the world faces. .. a crisis in our capacity to offer hospitality, to welcome those in need... the ones who have yet to come" (Iheka \& Taylor, 2018, p. 14). Whereas Richard moves eventually from his library to actual encounters with actual African migrants, and makes a home for them, two recent media sites offer a tamer vicarious meeting for those not yet ready to take such a step that might disrupt their actual lives. Both seek to engage viewers/ readers (Europeans, one assumes) vicariously in the lived experiences of particular Africans forced to flee their homes ${ }^{6}$,--exercises closer to an "equalizing" encounter than one had seen elsewhere in politics (Poland's Law and Justice party; Germany's Alternative for Germany; Italy's Lega Nord).? Funded by the Arts Council of England, the Netherland Film Fund, and various other groups, and organized by Alison Killing, Migration Trail is an imaginative tracing of two fictional characters, made up from the recounted experiences of many actual migrants, as they make a ten-day trip to Europe. The project is beautifully presented, and very engaging, and is written by a Nigerian and a Lebanese. Killing's Ted Talk, "Border Crossings," offers an inspiring but sobering account of what is at stake. Surprising Europe is a nine-part television series ${ }^{8}$ that charts the experiences of African migrants in Europe, in their own words, following them into the various dilemmas they face. The New York Times has offered a similar website that offers some sense of the dangers inherent in these desperate journeys (Heller). But as Véronique Machelidon and Patrick Saveau argue, such writers and filmmakers call for

6 See, as well, the critical video on this topic in the New York Times from Charles Heller et al: https://www. nytimes.com/interactive/2018/12/26/opinion/europe-migrant-crisis-mediterranean-libya.html Accessed 26 March 2019.

7 As well as France's National Rally, Finland's True Finns, Estonia's Conservative People's Party, Austria's Freedom Party of Austria, Hungary's Jobbik, Turkey's MHP, Greece's Golden Dawn, Armenia's Armenian Revolutionary Federation, the United Kingdom's UK Independence Party, Slovakia's Slovak National Party, and Denmark's Danish People's Party. The Economist reports in September of 2018, though, that "Although support for antiimmigrant parties across 13 European countries has doubled from $12.5 \%$ in January 2013 to $25 \%$ today, much of this is driven by sentiment in Germany, Italy and Poland, alone. That leaves open the possibility that the surging populist parties may simply be benefiting from charismatic leaders or unusually ill-advised immigration policies. In ten of the 13 countries conservative populists have actually lost ground relative to 2016." The Economist 18 September 2018 online (https://www.economist.com/graphic-detail/2018/09/10/ right-wing-anti-immigrant-parties-continue-to-receive-support-in-europe) Accessed 31 December 2018.

8 Anne Brenda Ochoa's concludes that the project "demonstrates how an online platform for mediated communication can be used to offer fragmented identities as well as a sense of belonging, offering a voice to the previously voiceless despite their migration status." See her full analysis of the project: "Representing African Migrants' Experience in Europe: A Study of Narratives on the Surprising Europe website." Stockholm University, Faculty of Humanities, Department of Media Studies, JMK, 2016 Independent Thesis Advance Level (Master's degree) http://su.diva-portal.org/smash/record.jsf?pid=diva2\%3A968050\&dswid=-4154 Accessed 26 March 2019. 
"a shift in the field of critical inquiry from the North Africa-France axis to a different, excentric pattern of trans-Mediterranean migrations, where refugee-migrants from the global South (including former French colonies), victims of war, ethnic cleansing, political strife, and environmental disasters, set their hope on 'burning' the intercontinental divide for various European destinations, and not exclusively, or preferentially, France" (Machelidon \& Saveau, 2018, p. 5). It remains to be seen whether or not Raspail was correct in his analysis: that this is "a problem absolutely insoluble by our present moral standards" (Raspail, 2017, p. 313).

Grant Support: The author received no financial support for this work.

\section{References}

Beardsley, E. (2018, June 29). "In the shadow of a terrorist attack, rapper is targeted by France's right wing." National Public Radio Music News. Online. https://www.npr.org/2018/06/29/623939587/in-the-shadow-ofa-terrorist-attack-rapper-is-targeted-by-frances-right-wing Accessed 3 July 2018.

Cohen, R. (2018, September 29). "Return of the German Volk." New York Times. Online (https://www.nytimes. com/2017/09/29/opinion/german-election-afd.html) Accessed 31 December 2018.

D'Addario, D. (2015, November 4). "Michel Houellebeca's Submission portrays a $21^{\text {st }}$ century French revolution" Time. Online http://time.com/4101182/a-21st-century-french-revolution/ Accessed 15 January 2019.

Erpenbeck, J. (2017). Go, Went, Gone. Trans. Susan Bernofsky. New York: New Directions.

Gopnik, A. (2015, January 20). "The next thing: Michel Houellebecq's Francophobic satire." The New Yorker online (https://www.newyorker.com/magazine/2015/01/26/next-thing) Accessed 31 December 2018.

Heller, C., Pezzani, L., Mann, I., Moreno-Lax, V., \& Weizman, E. (2018, December 26)."'It's an act of murder': how Europe outsources suffering as migrants drown." New York Times. Online https://www.nytimes.com/interactive/ 2018/12/26/opinion/europe-migrant-crisis-mediterranean-libya.html Accessed 26 December 2018.

Houellebecq, M. (2015). Trans. Stein, L. Submission. New York: Picador.

Iheka, C. \& Taylor, J., (Eds.), (2018). African Migration Narratives: Politics, Race, and Space. Rochester, NY: University of Rochester Press.

Killing, A. (2018). Migration Trail. https://www.migrationtrail.com/ Accessed 26 December 2018.

Killing, A. "Border Crossings." (2018). Ted Talk. Online https://www.youtube.com/watch?reload=9\&v= UUi3UCNvdLU Accessed 26 December 2018.

Machelidon, V. \& Saveau, P., (Eds.), (2018). Reimagining North African Immigration: Identities in Flux in French Literature, Television, and Film. Manchester, UK: Manchester University Press.

Ochola, A. (2016). “Representing African migrants' experience in Europe: a study of narratives on the Surprising Europe website." Stockholm University, Faculty of Humanities, Department of Media Studies, JMK, Independent Thesis Advance Level (Master's degree) http://su.diva-portal.org/smash/record.jsf?pid=diva2 $\% 3 A 968050 \&$ dswid $=-4154$ 
Raspail, J. (1973, 1985 [French]; 2017 [English]). Trans. Norman Shapiro. The Camp of the Saints. Detroit: Social Contract.

Shatz, A. (2015, April 9). “Colombey-les-deux-Mosquées." London Review of Books 37.7: 15-18. Online https:// www.Irb.co.uk/v37/n07/adam-shatz/colombey-les-deux-mosquees Accessed 15 January 2019.

Williamson, C. (2018). "Review of The Camp of the Saints." In: The Conservative Bookshelf. http://www.completereview.com/reviews/popfr/raspailj.htm. Accessed 15 January 2019.

Zaouiche, M. (2005, November 14). "How much more French can I be?" Time. Vol. 166, Issue 20. Online http:// eds.a.ebscohost.com.libproxy.scu.edu/eds/detail/detail?vid=1\&sid=2f09c01 b-abd4-4a05-b589-8c82772484d5 \%40sessionmgr4010\&bdata=JnNpdGU9ZWRzLWxpdmU\%3d\#AN=18768550\&db=ulh. Accessed 26 December 2018. 